\title{
Ubaldo Castagnoli. Dal Gruppo 7 alle architetture per le telecomunicazioni
}

Uliva Velo

Anna Castagnoli

Manuela Incerti

Abstract

II contributo presenta i primi esiti della ricerca condotta sulla figura dell'architetto Ubaldo Castagnoli, componente del Gruppo 7, espressione del nascente movimento moderno in Italia. Alla luce della cospicua ed inedita documentazione grafica conservata nei numerosi archivi consultati, saranno proposte alcune riflessioni su alcuni suoi progetti e la loro rappresentazione alle varie scale.

Parole chiave

Razionalismo, Gruppo 7, STIPEL, Ubaldo Castagnoli, archivi.

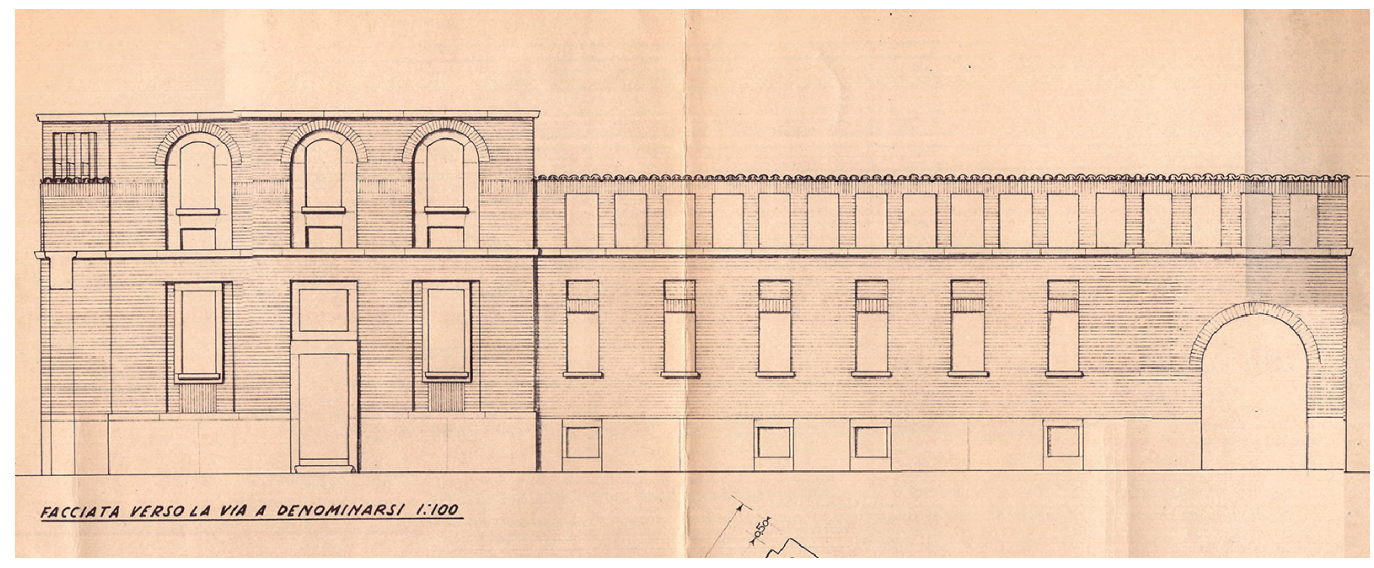




\section{Note biografiche}

Ad oggi, il nome dell'architetto Ubaldo Castagnoli è conosciuto solo per il suo subitaneo abbandono del Gruppo 7, sostituito da Adalberto Libera.

Dietro l'anonimato di un lavoro dirigenziale all'interno del gruppo STIPEL, è stato invece un architetto che ha lavorato per più di trent'anni a quella fusione tra industria, architettura, urbanismo e estetica così centrali nel manifesto del Razionalismo.

Nasce a Roma il 7 maggio 1902. Trasferitosi prima a Crema poi a Bergamo per il lavoro in banca di suo padre, intraprende gli studi di Architettura-Ingegneria presso il Regio Istituto tecnico superiore di Milano (che nel 1937 prenderà il nome di Politecnico).

II primo agosto 1925 si laurea in Ingegneria e Architettura e a dicembre dello stesso anno supera a Roma l'Esame di Stato. Nel 1926, un gruppo di sette amici formatosi tra i banchi del Regio Istituto sotto l'ala di Piero Portaluppi - allora assistente alla cattedra di Architettura - composto da Ubaldo Castagnoli, Luigi Figini, Gino Pollini, Guido Frette, Sebastiano Larco, Carlo Enrico Rava, Giuseppe Terragni, decide di unirsi e fondare il Gruppo 7, il primo gruppo di architetti moderni italiani [Ciucci, Muratore 20 I0; Cartasegna, Santi 20 I7].

I sette colleghi firmano con il nome Gruppo 7 quattro articoli fondamentali per la storia dell'architettura italiana. Comparsi a distanza di pochi mesi sulla rivista Rassegna Italiana tra dicembre 1926 e maggio 1927, questi articoli e il vivo dibattito che ne segui vengono ancora oggi considerati il manifesto della nuova architettura italiana.

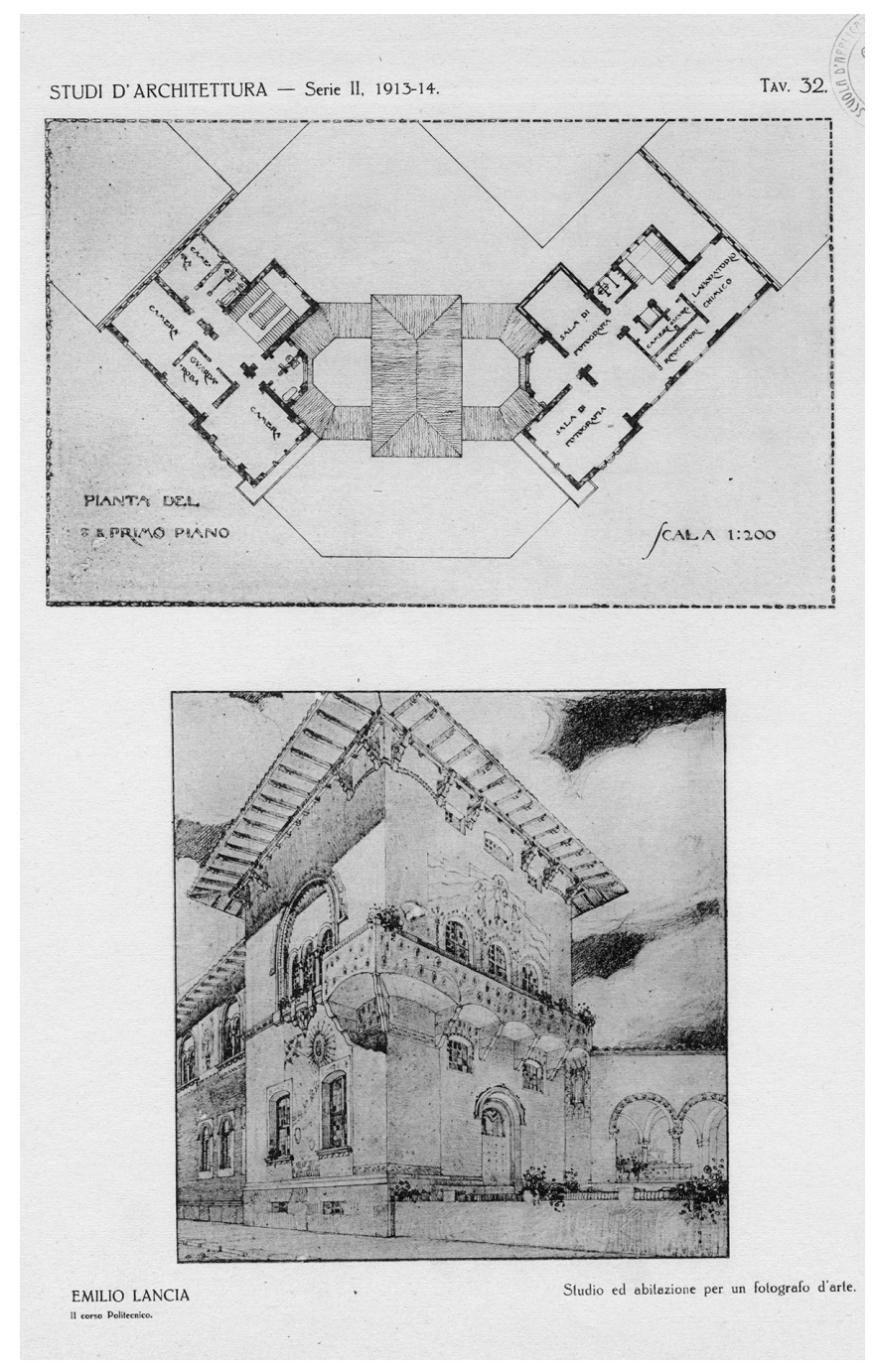


Fig. 2. Elaborati accademici di Ubaldo Castagnoli studente del Politecnico di Milano, 1924 circa (Mart, Archivio del '900, Fondo Figini-Pollini, fasc. Fig.-Pol. 3.1.2.1)
Gli articoli e la corrispondenza (conservata negli archivi Figini-Pollini al MART e alla Fondazione Le Corbusier di Parigi) che il Gruppo 7 intrattenne con i più grandi architetti moderni (tra gli altri, Le Corbusier, Walter Gropius, Hugo Häring, Erich Mendelsohn) lasciano emergere la volontà di trovare una architettura con caratteristiche sue proprie, in equilibrio tra la morbidezza dell'architettura mediterranea e l'essenzialità dell'architettura "puramente razionale", espressione utilizzata da Carlo Enrico Rava in una lettera di presentazione inviata a Le Corbusier, che firmerà: "Pour le 'gruppo 7', Carlo Enrico Rava, architecte".

Pochi mesi dopo, Castagnoli annuncia che vuole uscire dal gruppo per rispondere autonomamente a una richiesta di lavoro. Dalle memorie familiari emerge l'urgenza di Castagnoli, in quegli anni di spola quotidiana tra Bergamo e Milano, di trovare un lavoro stabile, per poter aiutare i fratelli a mantenersi agli studi e sposare Anita Pescali, bergamasca.

Non è ancora conosciuto per chi o all'ombra di chi lavorasse Castagnoli tra l'abbandono del Gruppo 7 nel '27 e l'assunzione STIPEL, avvenuta intorno al 1935, ma nelle lettere conservate al MART, Figini, risentito per l'abbandono del gruppo, scrive che Castagnoli aveva trovato quel lavoro grazie alla visibilità del Gruppo 7.
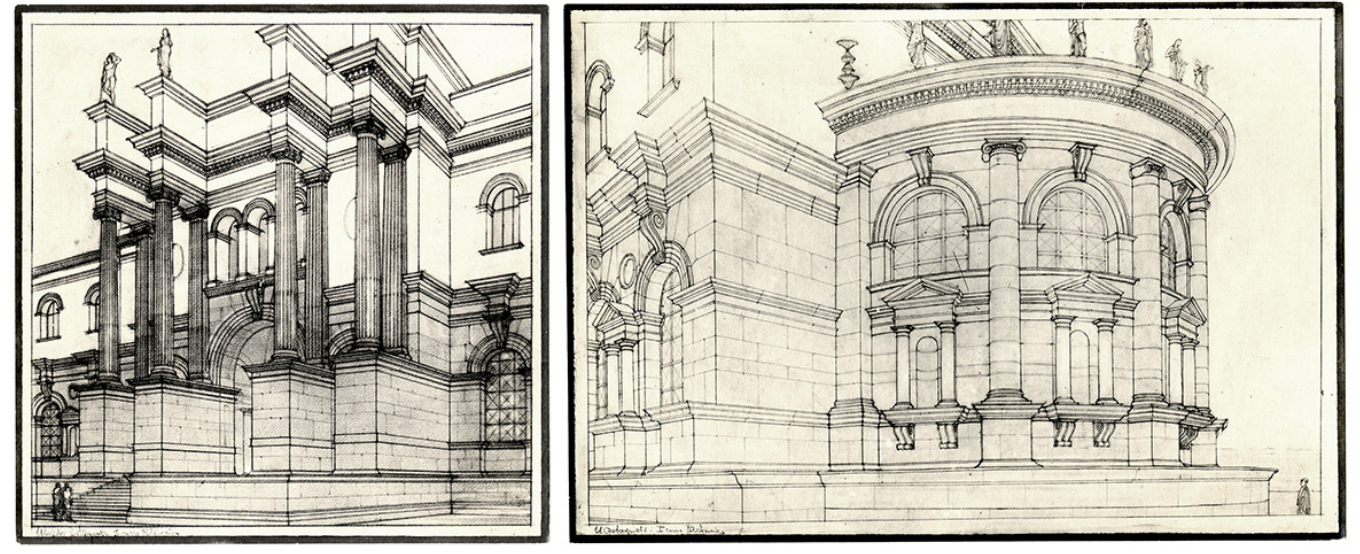

A Milano, Castagnoli condivide uno studio con Guido Frette, in via Rugabella 9 e, nel 1929 , realizza con lui una tomba per il cimitero israelitico di Milano (Archivio Figini-Pollini, MART, Fig. Pol.3.l.2.2); nel 1930 esegue alcuni bozzetti insieme a Piero Bottoni per nuovi interni del padiglione che Pirelli aveva commissionato a Piero Portaluppi nel 1926, mai realizzati (Archivio Bottoni, Op. 50 - Stand Pirelli alla Fiera di Milano, 1930); partecipa al concorso della IVTriennale di Monza con un progetto di villa al mare a Lussinpiccolo (Caneva, Griffini 1930), portandolo poi alla II Esposizione di architettura razionale italiana del 1931 e alla Permanente di Milano del 1931 (Rassegna di Architettura 1931); viene selezionato tra i 38 progetti di Case Popolari per il quartiere San Siro di Milano ( 1932) con un progetto urbanistico realizzato insieme a Antonio Cassi Ramelli (Istituto per le case popolari Milano 1933). Nel 1935 circa, accettata la proposta di assunzione della STIPEL, si trasferisce con la moglie a Torino. Avrà due figli, Anna-Maria e Giuseppe. Ubaldo Castagnoli lavorerà per l'azienda con la carica di direttore della sezione Direzione generale per gli affari immobiliari, curando in Lombardia, Piemonte e Valle d'Aosta la scelta di zone urbane, la progettazione di uffici, palazzi dei telefoni, centrali telefoniche e antenne. Dopo il 1957, per motivi di salute, darà le dimissioni (Archivio Storico TIM, lettera di dimissioni firmata da Enrico Basola del 5 luglio 1962) continuando comunque a lavorare per l'azienda come libero professionista, almeno fino al 1967.

Nella vasta opera, in fase di catalogazione, meritano attenzione: il ponte radio sul colle della Maddalena di Torino (anni Cinquanta), la sopraelevazione con piscina sul tetto del Palazzo dei Telefoni di Torino, la sopraelevazione del Palazzo dei Telefoni di Milano in via Negri, l'edificio di Città Studi e, infine, il restauro per il Presidente Luigi Einaudi della casa di Torino e del podere di Dogliani, subito dopo la seconda guerra mondiale. Muore a Torino nel 1982. 


\section{Castagnoli e la scuola milanese}

Castagnoli si laurea nel Regio Istituto tecnico superiore di Milano, istituzione fondata nel I863, i cui sviluppi [Selvafolta 2008; Selvafolta 20 I2] furono fortemente orientati dalla figura di Camillo Boito (I836-19|4) che vi insegnò, senza interruzioni, dal I865 al 1908. All'inizio del Novecento si laurearono nella scuola milanese: Piero Portaluppi e Enrico Agostino Griffini (19|0), Giovanni Muzio (19|5), Emilio Lancia e Mino Fiocchi (1919), Giuseppe Terragni e Gio Ponti (1921), Tommaso Buzzi (1923), Piero Bottoni e Luigi Figini (1926), Gino Pollini, Antonio Cassi Ramelli e Paolo Buffa (1927), figure con le quali Castagnoli entrò in contatto in tempi e circostanze diverse.

L'importanza e ruolo del disegno nella formazione dell'architetto-ingegnere emergono dai programmi e dalle metodologie didattiche [Buratti Mazzotta 20।3; Bernardi 20 I8], così come dai risultati dei corsi documentati nella raccolta di progetti curata da Gaetano Moretti in un'opera edita in memoria di Camillo Boito [Moretti s.d.]. I disegni attestano una chiara proposta didattica indirizzata verso soggetti progettuali di carattere monumentale affrontati attraverso un graduale approfondimento dei temi dell'ornamento, della forma e degli assetti distributivi (fig. I). Tra i giovani autori degli elaborati selezionati troviamo anche coloro che, spesso, sono stati riuniti intorno all'espressione Novecento milanese, cioè Lancia, Ponti e Fiocchi che, insieme a Muzio, costituiranno intorno al 1920 lo studio di via S. Orsola. Moretti, già dal 1908 titolare della cattedra di Architettura che era stata di Boito, con la collaborazione del suo assistente Piero Portaluppi, portava avanti l'esperienza storicistica del suo maestro, anche se parzialmente rinnovata alla luce di nuovi codici. A questo contesto formativo devono essere riferiti i disegni realizzati da Castagnoli studente, dunque precedenti al 1925, del tutto aderenti al consolidato indirizzo della scuola milanese (figg. 2-5). In quegli anni, come ricorda in una intervista Guido Frette (compagno di studi dal 1919 al 1923) "passavamo la maggior parte del nostro tempo in aula da disegno" e ancora "in tutta la scuola eravamo in venticinque e stavamo dalle sette-otto ore in aula da disegno" [Cartasegna, Santi 2017, pp. 35 e 39].

Fig. 3. Ubaldo Castagnoli, Chiostro di Santa Maria della Pace, Roma, 1921-1922 (Archivio privato famiglia Castagnoli), acquerello su carta.

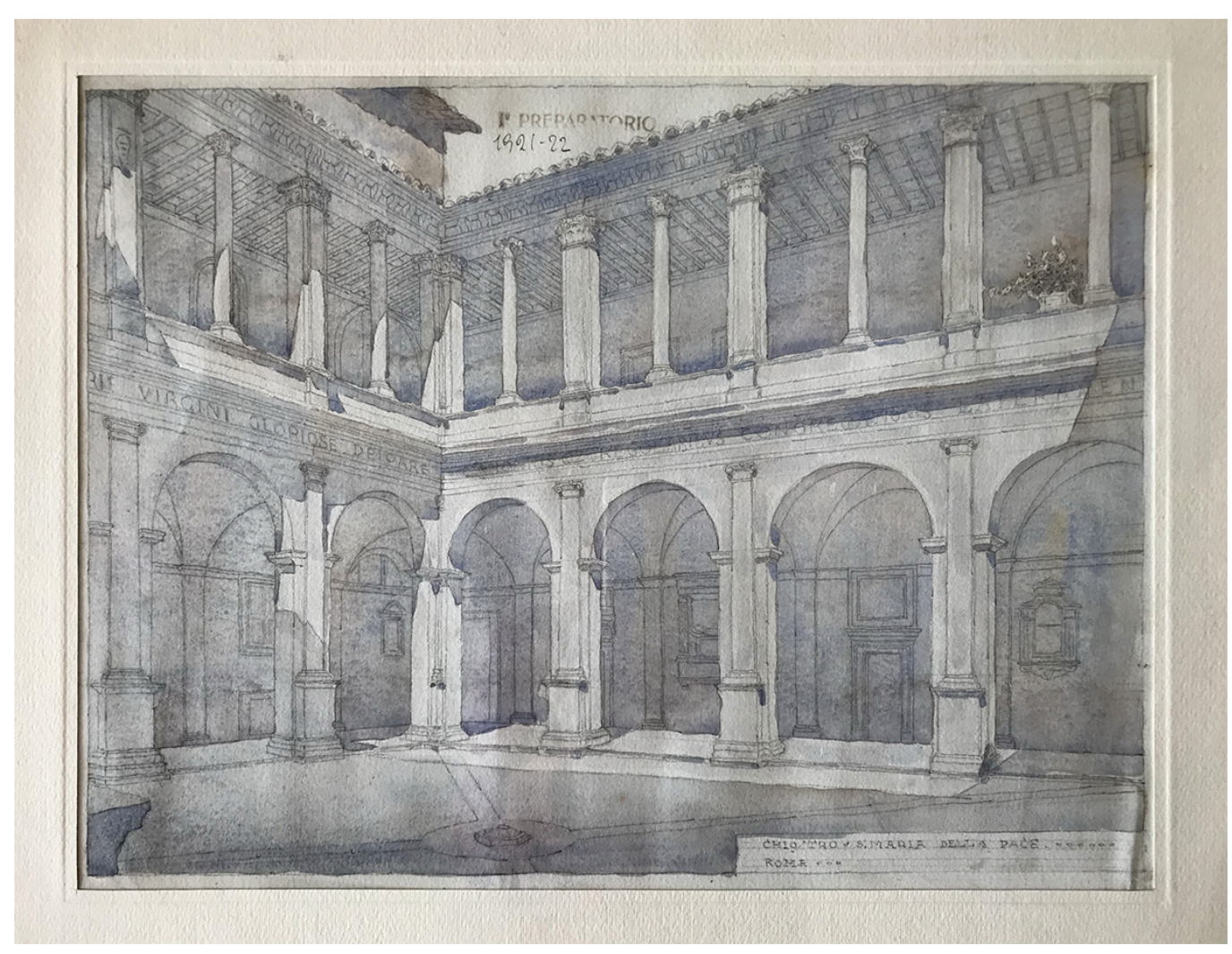


Solamente un anno dopo la laurea, con il proposito di rinnovare il pensiero architettonico comune e la ricerca formale e funzionale dell'edilizia italiana, il giovane architetto partecipa alla costituzione del Gruppo 7 che, ispirandosi alle istanze del Movimento Moderno, utilizzava anche nuovo linguaggio grafico da lui risolutamente adottato nel progetto della villa per la IV triennale di Monza [Caneva, Griffini 1930, pp. 55-59; Incerti 2016, p. I 85]. Come racconta ancora Frette, il Gruppo 7 tuttavia non abbandonò mai la tradizione, "Le Corbusier l'ha abbandonata completamente anche nei disegni, noi no. La differenza tra noi e gli altri razionalisti europei sta proprio lì, quelli erano più scarni ed essenziali di noi, noi avevamo ancora il ricorso di cose viste fino a quel momento" [Cartasegna, Santi 20 I7, p. 39].

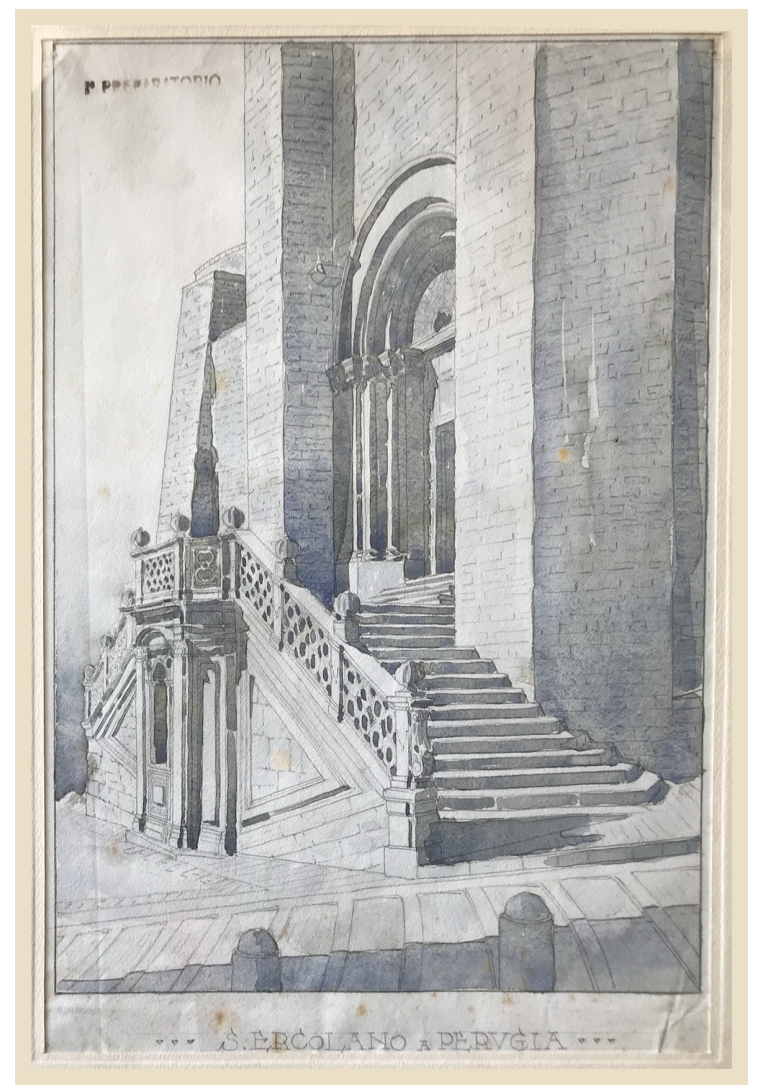

\section{Il disegno di Castagnoli per le arti applicate}

Molto c'è da indagare sulle indubbie qualità di questo progettista poco conosciuto. È interessante mostrare come fin dall'inizio della sua vita professionale abbia fatto parte di una tendenza verso l'innovazione, come si vede già nel logo del Gruppo 7 concepito secondo una grafica lineare e geometrica (fig. 6).

Ubaldo Castagnoli è stato un professionista tipico del suo tempo. Difatti egli ha avuto una formazione ampia e nutrita e ha espresso la propria progettualità in diversi campi spaziando tra ricerche tecniche, visioni urbanistiche, studio di interessanti soluzioni architettoniche, fino a cimentarsi col disegno di oggetti.

Dalla metà degli anni Venti le Arti decorative si stavano trasformando anche in Industriali, per cui accanto a rinomati disegnatori e agli artigiani realizzatori si affianca anche una nuova idea di strategia della diffusione del prodotto e della sua riproducibilità.

Castagnoli si trova a fare parte di un fervido periodo in questo senso e viene coinvolto, insieme ad altri colleghi, a creare forme per oggetti d'uso. 
II connubio si fa particolarmente interessante poiché l'idea innovativa propria della sua architettura trova spazio anche qui, pur con alcuni limiti: la doppia veste da una parte novecentista, derivata dai linguaggi studiati durante la formazione, e dall'altra razionalista personale ricerca espressiva, è abbastanza evidente nei pochi oggetti noti di sua firma. Si tratta infatti di due volti, quello novecentista e quello razionalista, compresenti nella gran parte degli architetti del tempo, come ormai riconosciuto.

II milieu delle esposizioni di arti decorative, prima Biennale a Monza (1923-1930) e poi Triennale a Milano (dal 1933), ruotava intorno a figure chiave con cui Castagnoli aveva rapporti stretti e egli vi partecipò sia come progettista con la razionalista Villa al mare (1930) [Velo 20।6, pp. 120-122] sia come designer con un piatto sbalzato nel 1933 (fig. 7) di sapore tradizionale novecentista (si vedano le realizzazioni di Giovanni Guerrini ad esempio in: Colombo Guerrini 2012) e con altri due oggetti nel 1936.

II primo è una coppa documentata dall'eliografia di un disegno autografo [I] databile tra $\mathrm{i}$ 1933 e il 1936, allorquando Castagnoli idea oggetti per la Cooperativa Artieri Alabastro di Volterra per la V e la VITriennale di Milano [Frattani, Badas 1976, p. 261 ; Turrini 20I8, p. 92]. II disegno è molto accurato e parlante: l'autore infatti ha rappresentato l'effetto del minerale da utilizzare con scrupolosità, curando quindi l'aspetto estetico dell'oggetto. Allo stesso tempo sulla parte sinistra del prospetto della coppa si leggono chiaramente due versioni per la curvatura interna della stessa: una prima a linea continua come a tracciare la sezione dell'oggetto, una seconda invece tratteggiata indica una curvatura più dolce e meno profonda. Siamo di fronte ad un elaborato che potremmo definire esecutivo, in cui la consapevolezza del tratto rende del tutto chiara l'idea.

Avendo rintracciato negli archivi della Triennale la fotografia di una coppa del 1936 del tutto uguale a quella del disegno dell'archivio volterrano e non attribuita (fig. 8), si può presupporre che sia la realizzazione di quella disegnata da Castagnoli. Dal punto di vista del materiale, pur essendo una foto in bianco e nero, s'intuisce che la realizzazione è di una coppa tornita in agata, come da doppia indicazione sul disegno (il riferimento all'arabescato rosso si trova

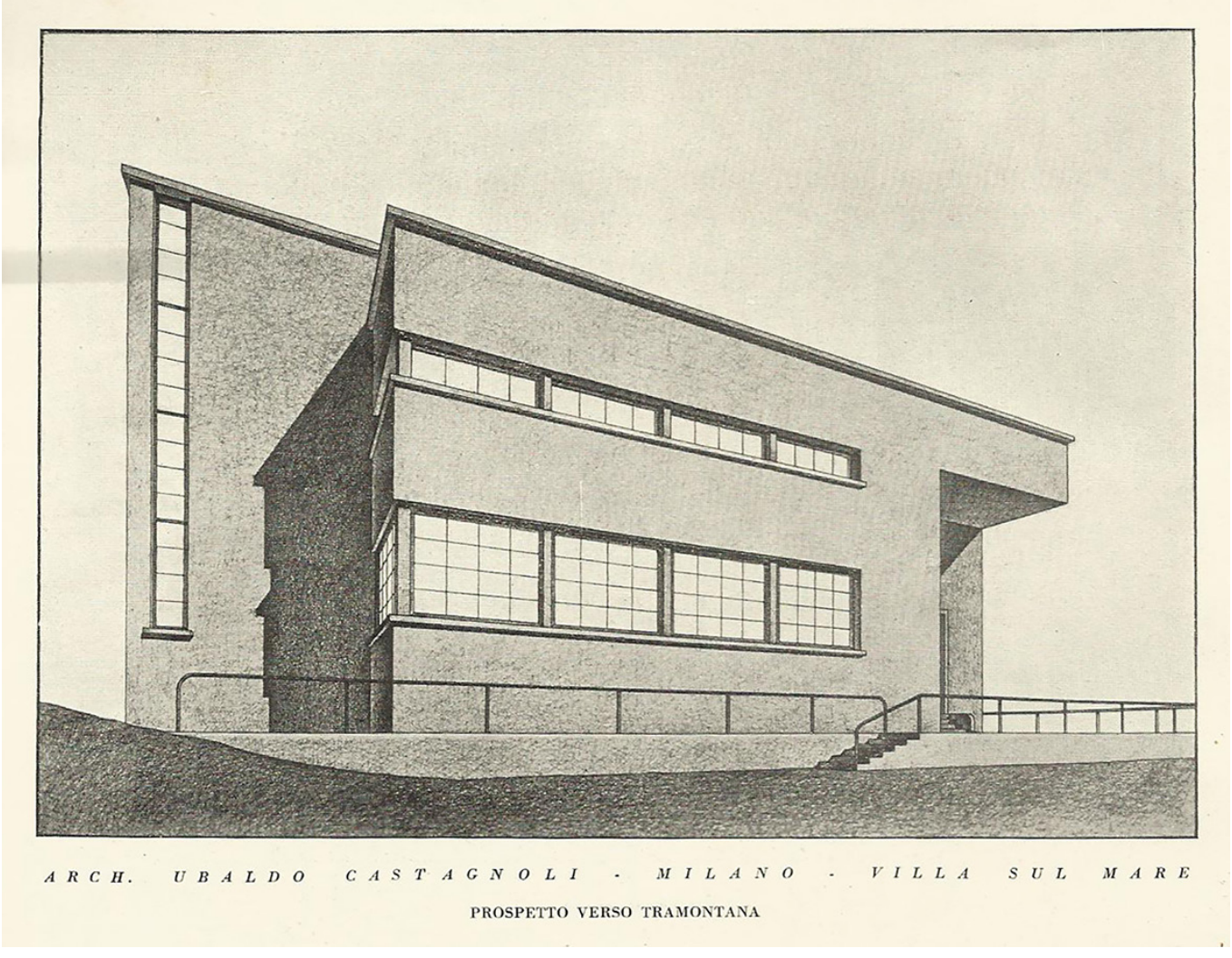


nellintestazione, mentre agata è scritto in corsivo in due punti del foglio); comunque era abbastanza comune usare dei prototipi declinati in diverse versioni materiche. Da notare sono le rigature scolpite nella pietra alla base della coppa e, molto sottili, su bordo superiore, motivo che si ritrova anche nella scatola in legno coeva (fig. 9). Qui, al corpo dell'oggetto estremamente lineare e moderno, si abbina un tappo decorato più in stile art déco.

Le collaborazioni di Castagnoli con colleghi sono state molteplici nei vari ambiti, come membro del Gruppo 7 innanzitutto, come progettista creando sodalizi duraturi nonché come designer muovendosi nelle relazioni con artigiani e artisti realizzatori tramite organizzazioni specifiche. La più significativa è l'ENAPI, Ente Nazionale per l'Artigianato e le Piccole Industrie, che aveva lo scopo, tra gli altri, di promuovere e sviluppare l'attività economica ed il perfezionamento tecnico dell'artigianato e delle piccole industrie attraverso forme di assistenza tecnica e artistica e il cui Direttore artistico dal 1927 al 1946 fu G. Guerrini che promosse proprio il connubio tra artisti/designer e artigiani. Per quanto concerne i suoi rapporti personali con figure di spicco del tempo, ricordiamo Antonio Cassi Ramelli con cui partecipò al concorso per le Case Popolari di Milano nel quartiere San Siro del 1932 [Rassegna di Architettura 1934] e continuò a collaborare in qualità di dipendente STIPEL coinvolgendo Cassi Ramelli in alcuni interventi (ad esempio per il progetto della sede Cavour di Milano), come si evince dagli scambi epistolari conservati nell'Archivio Storico TIM. Cassi stesso poi fu il progettista della sede STIPEL di Pavia (1954-56), fatto che sta ad indicare l'intreccio di contatti e rapporti nel quale Castagnoli era coinvolto (basti pensare che l'incarico alla STIPEL gli fu possibile grazie a relazioni avute attraverso il Gruppo 7).

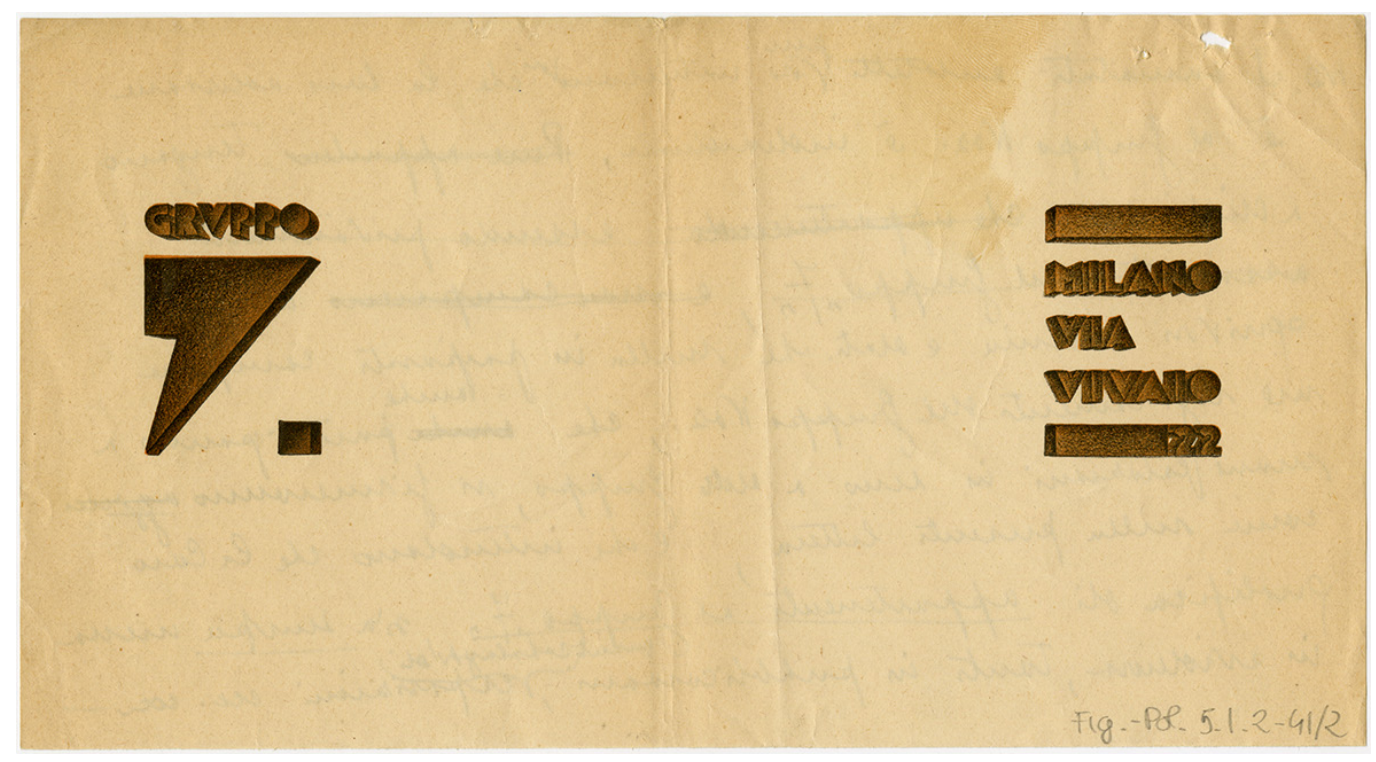

\section{Uno dei primi progetti per STIPEL: l'edificio in Città Studi a Milano}

La crescita di abbonati della STIPEL (Società telefonica interregionale piemontese e lombarda) in una zona di forte espansione come quella di Città Studi e l'impossibilità di ampliare gli spazi occupati dai macchinari già in uso, portarono l'azienda a programmare nel febbraio 1938 l'abbandono dei propri locali siti nell'edificio principale del R. Politecnico di Milano e a progettare una nuova sede.

L'urbanizzazione di quest'area periferica e rurale era iniziata nel 19/3 con il progetto di massima dell'intero complesso universitario curato dai due docenti Augusto Brusconi e Gaetano Moretti [Ricci 2008]. La realizzazione di questa imponente opera, costituita da nove edifici fra loro collegati, era stata avviata nel 1915 e, dopo il blocco del periodo bellico, era ripresa nel 1921 con la redazione del progetto definitivo sino all'inaugurazione del 1927. 
Fig. 7. Piatto sbalzato

eseguito dalla ditta Nani

di Bergamo, disegno

dell architetto Ubaldo

Castagnoli, esposto nella

sala dell'E.N.A.P.I. della

Mostra internazionale

delle arti decorative e

industriali, 1933

(foto: Crimella).

Fig. 8. A sinistra: disegno di coppa al tornio in

arabescato rosso, firmato

Ubaldo Castagnoli, matita

su carta, Archivio Storico

della Cooperativa Artieri

Alabastro di Volterra,

1933-1936. A destra:

coppa, esposta nella

Galleria delle arti deco-

rative e industriali della $\mathrm{VI}$

Triennale di Milano, 1936

(foto: Crimella).
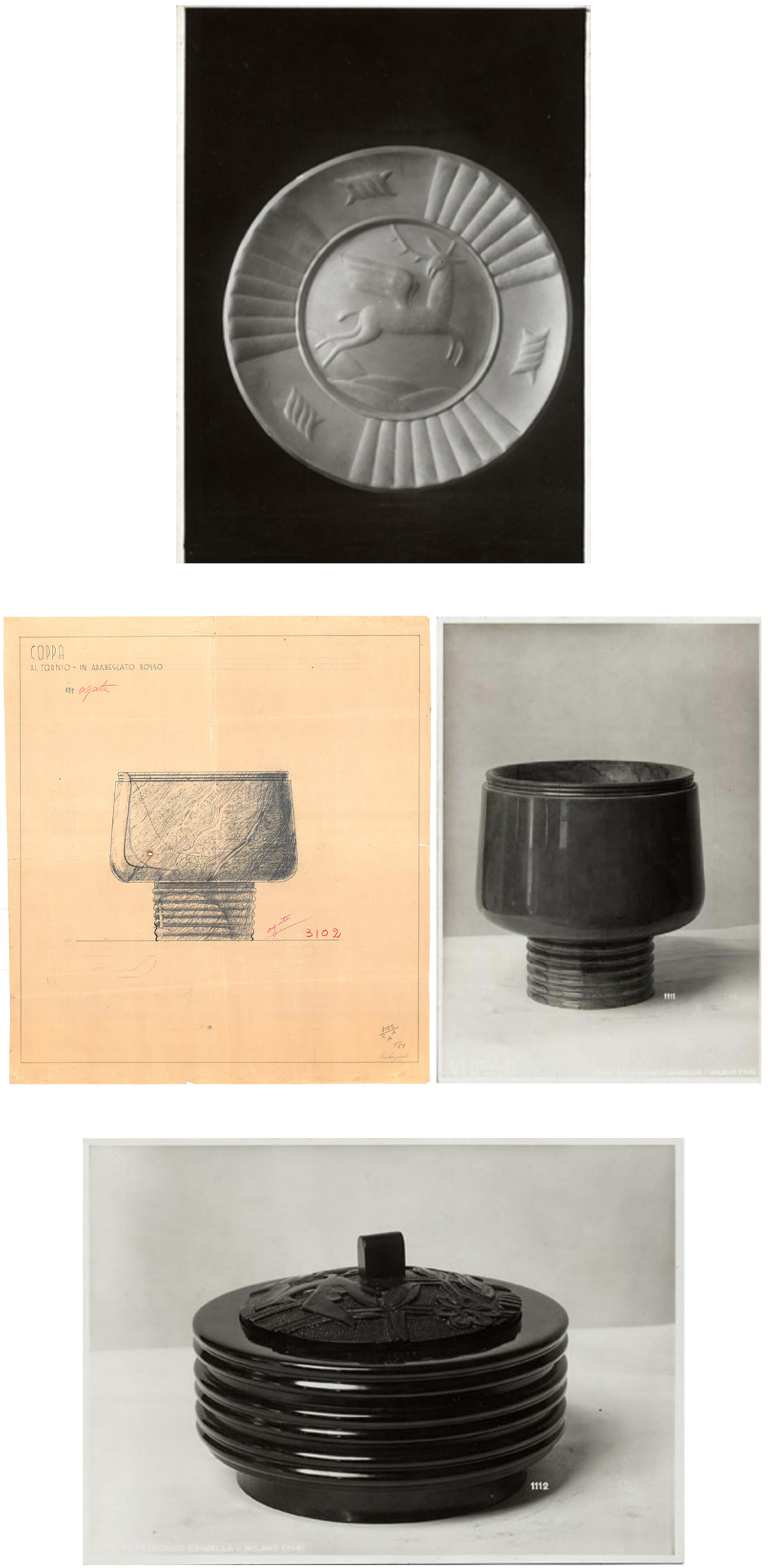
Fig. I0 Nuova centrale STIPEL di Città Studi.A partire dal pentagono irregolare del lotto, Castanoli sviluppò un edificio redício un piccolo cortile. Al piano seminterrato erano no seminterato erano locali tecnici e i magazzini mentre al piano rialzato erano la grande sala

denominata "automatico", di circa 300 mq, e la sala macchine. Lalloggio per il personale fu posto al piano primo. Uno schizzo testimonia che, al posto della copertura curva, fu in realtà realizzato un tradizionale tetto a falde (Archivio Storico TIM faldone $7 / 2$ ).

Fig. I I. Nuova centrale STIPEL di Città Studi. La composizione della facciata è caratterizzat da lievi arretramenti dei piani, necessari per scandire il ritmo insieme alle aperture. Le finestre rimarcate da grandi cornici lapidee e alti davanzali, insieme alla tessitura dela murara in atura, sono disegnate in una tavola di dettaglio in scala 1.20. In sommitá, il tema della loggia con architrave viene trattato diversamente sul lato sud-ovest (chiusa) rispetto ad est (aperta) (Archivio Storico TIM, faldone 7/2).

Fig. 12. Progetto di sopraelevazione dell'edificio di Città Studi datato 1962: al corpo centrale su Piazza Leonardo fu aggiunto un piano, mentre su via Spinoza fu demolita la copertura della "sala automatico" per aggiungere altri due pamiglia Castagnoli).
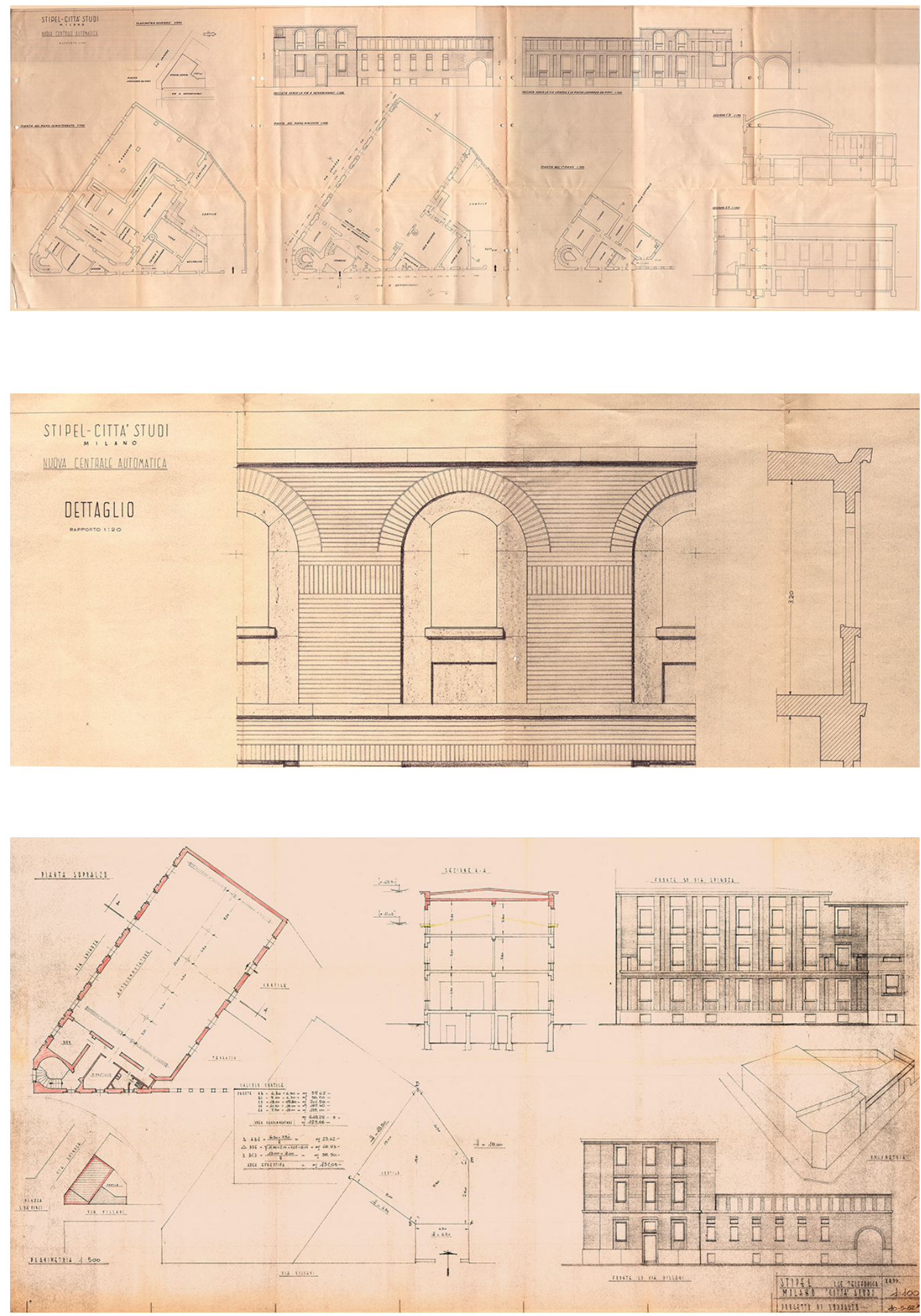
La forma planimetrica della nuova centrale è il risultato di una serie di contrattazioni intercorse con le proprietà e l'amministrazione locale che autorizzò l'uso di una porzione dell'area posta a nord-ovest di Piazza Leonardo dove, nell'immediato dopoguerra (1919), a seguito della carenza di abitazioni popolari, era stato edificato il Villaggio giardino Gran Sasso. Gli espropri e le demolizioni degli immobili residenziali, avvenuti nel 1939, segnano il principio della fase esecutiva del progetto che fu realizzato tra il 1940 e il 1943 (dunque durante la guerra) così come attestano i contratti con l'impresa esecutrice (Archivio Storico TIM - Fondo STIPEL - Serie DCT, Direzione Centrale Tecnica - Subserie SE, Servizio Edile - Faldone 7/2).

II disegno dei prospetti manifesta l'uso di un linguaggio contemporaneo: le coperture sono percepite visivamente come piane, anche se il tetto della grande sala macchine ha una sezione ad arco ribassato (con luce di I4 m) celata da una piccola veletta (figg. I0- I2). Si tratta di una soluzione tecnologicamente e geometricamente innovativa per l'epoca visto che, solo nel 1938, nel settore dell'edilizia alla Fiera campionaria di Milano era stata esposta la struttura ad arco con travi in laterizio armato detta Volta SAP per grandi coperture (fino a 15 metri), sistema brevettato nel 1936 e prodotto dalle Fornaci fratelli Rizzi Donelli Breviglieri \& C. di Piacenza. La medesima tecnologia fu utilizzata da Giuseppe Pagano nel progetto di ampliamento dell'edificio della Nuova Pettinature Riunite a Biella del 1939, in collaborazione con l'ing. Predaval [Paolini, Pugnaletto 2017].

Forme circolari e semicircolari caratterizzano la pianta dell'ingresso, quella del vano scale, le aperture del secondo livello, i due archi di accesso all'attuale via Villani (mai conclusi anche se impostati come si può vedere dal frammento ancora oggi esistente) e quello di ingresso alla corte. Se la declinazione di tali geometrie è innegabilmente prossima al linguaggio novecentista milanese, l'uso della tecnologia della Volta SAP evidenzia l'attenzione progettuale di Castagnoli verso soluzioni costruttive innovative.

Con queste prime riflessioni, appena delineate, prende il via una nuova ricerca sulla figura dell'architetto Castagnoli, componente del Gruppo 7, che sarà condotta sulla base della inedita e cospicua documentazione grafica conservata nei numerosi archivi consultati [2].

\section{Note}

[I] Uno dei disegni inediti, appartenente all'Archivio Storico della Cooperativa Artieri Alabastro di Volterra, disponibile grazie a un progetto di ordinamento e schedatura con responsabile scientifico Prof. D. Turrini, Università degli Studi di Ferrara Dipartimento di Architettura, Finanziamento MIBACT - Direzione Generale per gli Archivi (Servizio III - Studi e Ricerche), 2014-2017, supervisione Soprintendenza Archivistica per la Toscana.

[2] Uliva Velo ha scritto il paragrafo II disegno di Castagnoli per le arti applicate; Anna Castagnoli ha scritto il paragrafo Note biografiche; Manuela Incerti ha scritto i paragrafi Castagnoli e la scuola milanese e Uno dei primi progetti per STIPEL: I'edificio in Città Studi a Milano.

\section{Riferimenti bibliografici}

Bernardi llaria, Aguirre Álvaro Soto (2018). L'apprendimento della rappresentazione dell'architettura: Figini e Pollini nell'età del Gruppo 7. In Disegnare. Idee Immagini, 56, 2018, pp. 80-91.

Buratti Mazzotta Adele (20 I3). La didattica del disegno edile e la cultura delle scuole tecniche nell'Ottocento a Milano. In: C. G. Lacaita, M. Fugazza (a cura di). L'istruzione secondaria nell'Italia unita: I 86 I - 1 90 I. Milano: FrancoAngeli, pp. 258-273.

Caneva Luigi Maria, Griffini Enrico Agostino (1930). 36 progetti di ville di architetti italiani. Milano-Roma: Bestetti e Tumminelli.

Cartasegna Roberto, Santi Brunetta (a cura di). (20 I7). Franca Petocchi intervista Guido Frette. In Brunetta Santi, Cartasegna Roberto ( acura di). Guido Frette un razionalista a Tortona. Catalogo della Mostra, Biblioteca Civica di Tortona 26.XI.2016 25.II.20 17. Tortona: Città di Tortona, pp. 33-45.

Ciucci Giorgio, Muratore Giorgio (20 I0). Storia dell'architettura italiana. Il primo Novecento. Milano: Electa.

Colombo Guerrini Elisabetta (2012). Giovanni Guerrini. Metalli, Imola: La mandragora.

Frattani Paola, Badas Roberto (1976). 50 anni di arte decorativa e artigianato in Italia. L'Enapi dal 1925 al 1975. Roma: Enapi.

Incerti Manuela (2016). Le ville del concorso della IV Triennale di Monza (1930). Disegno e modello nella comunicazione del progetto. Bologna: Bononia University Press. 
Istituto per le case popolari Milano (1933). Il concorso pel nuovo quartiere Francesco Baracca a San Siro : progetti di massima pel nuovo quartiere Maurilio Bossi in viale Molise. Milano: Bertieri.

Moretti Gaetano (a cura di), (sd). Studi di architettura della scuola superiore nella R. accademia di Belle Arti e nel R. Politecnico di Milano. Milano: Bestetti e Tuminelli.

Paolini Cesira, Pugnaletto Marina (2017). Reinforced brick light-weight vaults. In Tema: Technology, Engineering, Materials and Architecture, 3, I, 6 luglio 2017, pp. 124-136.

Rassegna di Architettura (193I). La II Esposizione di Architettura Razionale Italiana alla Permanente di Milano. In Rassegna di Architettura, IX, 7, I931, pp. 249-257.

Rassegna di Architettura (1934). P. Buffa, A. Cassi architetti. In Rassegna di Architettura, num. spec., 1934.

Ricci Giuliana (2008). Una sede sofferta: dalla preesistenza a un nuovo insediamento urbano. In Annali di storia delle universita italiane, 12. Bologna: Clueb, pp. 27-44.

Selvafolta Ornella (2008). Una scuola per il progetto. La formazione tecnico scientifica al Politecnico di Milano. In Milano scientifica, 1875-1924. Milano: Sironi.

Selvafolta Ornella (20/2). Gli studi di ingegneria civile e di architettura al Politecnico di Milano. Territorio, costruzioni, architetture. In Le università e l'unità d'Italia, 1848-1870. Bologna: Clueb.

Turrini Davide (20 I8). Alabastro e design. Gli Artieri di Volterra dal 1933 al 1953. In LUK, 24, 20 I8, pp. 85-96.

Velo Uliva (2016). La «villa moderna». Riletture dei progetti di concorso. In: Incerti Manuela. Le ville del concorso della IV Triennale di Monza (1930). Disegno e modello nella comunicazione del progetto. Bologna: Bononia University Press, pp. I03-I49.

\section{Autori}

Uliva Velo, Università di Ferrara, uliva.velo@unife.it

Anna Castagnoli, Università di Ferrara, anna.castagnoli@gmail.com

Manuela Incerti, Università di Ferrara, manuela.incerti@unife.it

Per citare questo capitolo: Velo Uliva, Anna Castagnoli, Incerti Manuela (2020). Ubaldo Castagnoli. Dal Gruppo 7 alle architetture per le telecomunicazioni/Ubaldo Castagnoli. From Gruppo 7 to architectures for telecommunications. In Arena A., Arena M., Brandolino R.G., Colistra D., Ginex G., Mediati D., Nucifora S., Raffa P. (a cura di). Connettere. Un disegno per annodare e tessere. Atti del $42^{\circ}$ Convegno Internazionale dei Docenti delle Discipline della Rappresentazione/Connecting. Drawing for weaving relationships. Proceedings of the 42th International Conference of Representation Disciplines Teachers. Milano: FrancoAngeli, pp. 2869-2890. 


\section{Ubaldo Castagnoli. From Gruppo 7 to Architectures for Telecommunications}

Uliva Velo

Anna Castagnoli

Manuela Incerti

\section{Abstract}

The following paper presents the first results of the research conducted on the figure of architect Ubaldo Castagnoli, a member of Gruppo 7, an expression of the nascent modern movement in Italy. Considering the conspicuous and unpublished graphic documentation kept in the numerous archives consulted, some reflections on some of his projects and theirs representation at various scales will be proposed.

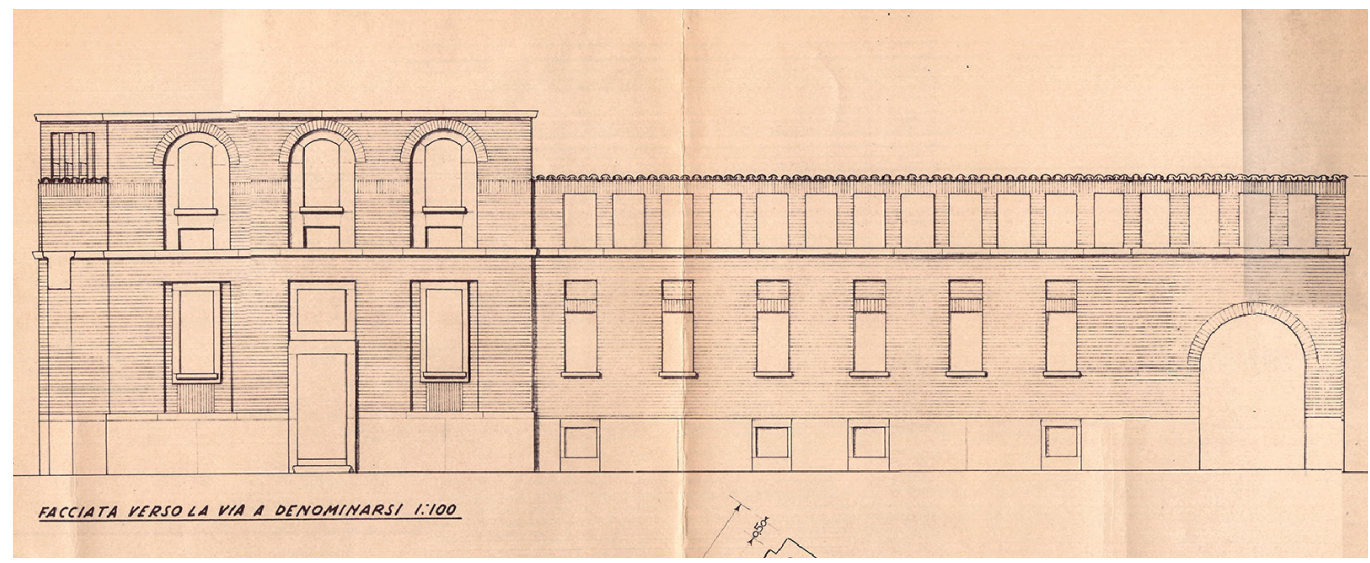




\section{Biographical notes}

Today, the name of the architect Ubaldo Castagnoli is only known for his sudden abandonment of Gruppo 7, replaced by Adalberto Libera.

Behind the anonymity of managerial work within the STIPEL group, he was actually an architect who worked for more than thirty years on the fusion between industry, architecture, urban planning and aesthetics that is so central to the manifesto of Rationalism.

He was born in Rome on May 7, 1902. He first moved to Crema and then to Bergamo for his father's banking job. He then began studying Architecture-Engineering at the Regio Istituto tecnico superiore di Milano (which would take the name of Politecnico in 1937).

On August I, 1925 he graduated in Engineering and Architecture and in December of the same year he passed the State Exam in Rome. In 1926, a group of seven friends decide to found Gruppo 7, the first group of modern Italian architects [Ciucci, Muratore 20 I0; Cartasegna, Santi 20 I7]. They had met among the classes of the Regio Istituto under the wing of Piero Portaluppi -then assistant to the chair of Architecture- and are Ubaldo Castagnoli, Luigi Figini, Gino Pollini, Guido Frette, Sebastiano Larco, Carlo Enrico Rava, Giuseppe Terragni. The seven colleagues sign four articles that have become fundamental to the history of Italian architecture under the name Gruppo 7. Appearing a few months later in the magazine Rassegna Italiana between December 1926 and May 1927, these articles and the lively debate that followed are still considered the manifesto of the new Italian architecture to date.

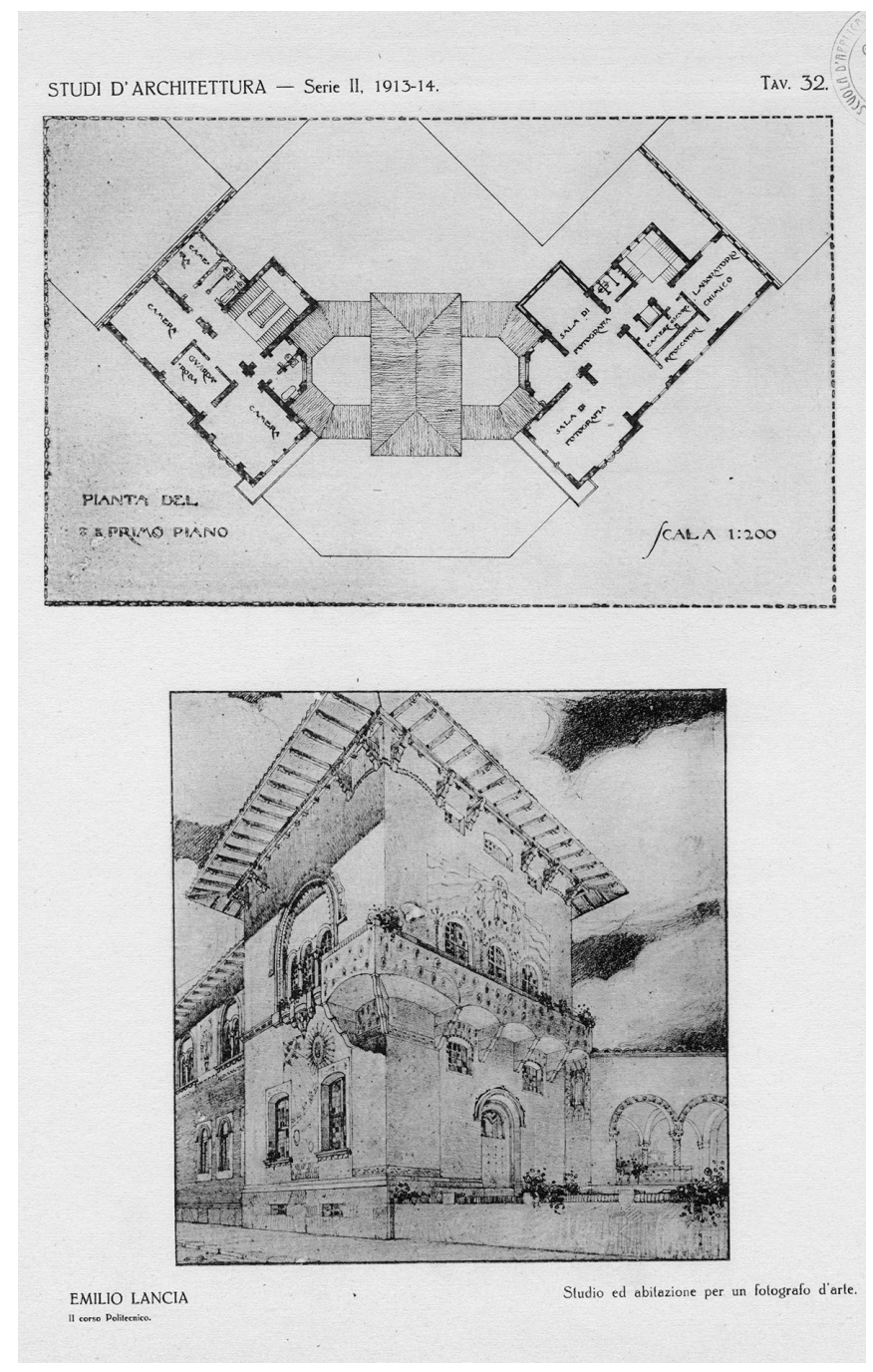


Fig. 2. Drawing by Ubaldo Castagnoli as a student of Politecnico di Milano, 1924 about (Mart, Archivio del '900, Fondo Figini-Pollini, fasc. Fig.-Pol. 3.1.2.1)
The articles and correspondence (kept in the Figini-Pollini archives at MART and at the Le Corbusier Foundation in Paris) that Gruppo 7 had with the greatest modern architects (among others, Le Corbusier, Walter Gropius, Hugo Häring, Erich Mendelsohn) shows the will to find an architecture with its own characteristics, in balance between the softness of Mediterranean architecture and the essentiality of 'purely rational' architecture, an expression used by Carlo Enrico Rava in a presentation letter sent to Le Corbusier, who will sign: "Pour le 'gruppo 7', Carlo Enrico Rava, architecte".

A few months later, Castagnoli announces that he wants to leave the group to independently respond to a job request. From family memories, the urgency of Castagnoli to find a stable job in those years of daily commute between Bergamo and Milan emerges, helping his brothers to stay in school and marrying Anita Pescali, from Bergamo.

It is still unknown for whom or in the shadow of whom Castagnoli worked between the abandonment of Gruppo 7 in 1927 and employment with STIPEL, which took place around 1935. In the letters kept at MART, Figini, resentful of the abandonment of the group, writes that Castagnoli had found that job thanks to the visibility of Gruppo 7.
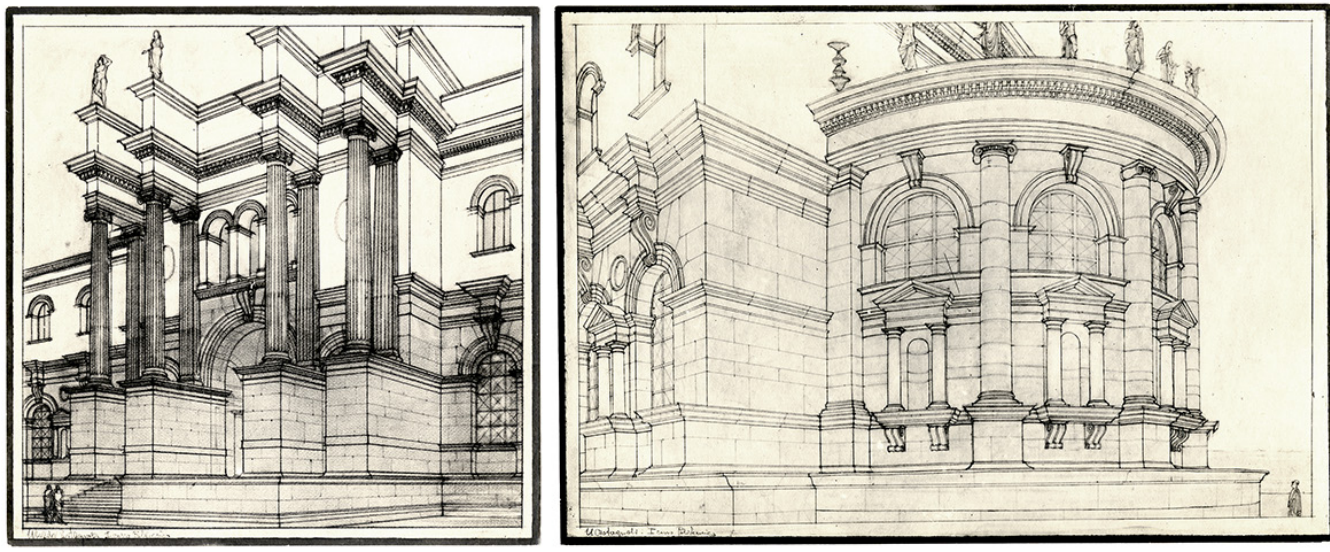

In Milan, Castagnoli shares a study with Guido Frette in via Rugabella 9 and, in 1929, designs a tomb with him for the Jewish cemetery in Milan (Archivio Figini-Pollini, MART, Fig. Pol.3.l.2.2). In 1930 he worked on some sketches with Piero Bottoni for new interiors of the pavilion that Pirelli had commissioned to Piero Portaluppi in 1926 but was never built (Bottoni Archive, Op. 50 - Pirelli stand at the Milan Fair, 1930). He participates in the competition of the IVTriennale of Monza with a project of a villa by the sea in Lussinpiccolo [Caneva, Griffini 1930], then taking it to the II Esposizione di architettura razionale in 1931 and to the Permanente di Milano in 1931 [Rassegna di Architettura 1931]. In 1932 he was selected among the 38 projects of Popular Houses for the San Siro district of Milan, with an urbanistic project carried out together with Antonio Cassi Ramelli [Istituto per le case popolari Milano, 1933]. In about 1935, having accepted employment at STIPEL, he moved with his wife to Turin. He will have two children, Anna-Maria and Giuseppe. Ubaldo Castagnoli will work for the company with the position of director of the Directorate-General for Real Estate Affairs section, taking care of the choice of urban areas, the design of offices, telephone buildings and antennas in Lombardy, Piedmont and Valle d'Aosta. After 1957 he resigned for health reasons (Archivio Storico TIM, resignation letter signed by Enrico Basola of 5 July 1962), continuing to work for the company as a freelancer at least until 1967.

In the vast works currently being catalogued, the following deserve attention: the radio bridge on the Maddalena hill in Turin (1950s), the elevation with swimming pool on the roof of the Telephone Building in Turin, the elevation of the Telephone Building in Milan in via Negri, the Città Studi building and the restoration of the Turin house and of the Dogliani farm for the President Luigi Einaudi immediately after the Second World War. Ubaldo Castagnoli died in Turin in 1982. 


\section{Castagnoli and the Milanese school}

Castagnoli graduated from the Regio Istituto tecnico superiore di Milano, an institution founded in I 863 whose development [Selvafolta 2008; Selvafolta 20 I2] was strongly influenced by the figure of Camillo Boito (1836-19|4), who taught there without interruption from 1865 to 1908. At the beginning of the twentieth century, Piero Portaluppi and Enrico Agostino Griffini (19/0), Giovanni Muzio (19/5), Emilio Lancia and Mino Fiocchi (1919), Giuseppe Terragni and Gio Ponti (1921), Tommaso Buzzi (1923), Piero Bottoni and Luigi Figini (1926), Gino Pollini, Antonio Cassi Ramelli and Paolo Buffa (1927) also graduated from the Milanese school. Castagnoli met these various figures in different times and under different circumstances.

The importance and the role of drawing in the education of the architect-engineer emerges from the didactic programs and methodologies [Buratti Mazzotta 20।3; Bernardi 20 I8]. It can also be seen from the results of the courses documented in the collection of projects curated by Gaetano Moretti in a work edited in memory of Camillo Boito [Moretti sd]. The drawings attest to a clear didactic proposal, addressing monumental design subjects through a gradual study of the themes of ornamentation, shape and distribution structures (fig. I). Among the young authors of the selected works, we can observe those who often gathered around the movement of Milanese twentieth century expression, namely Lancia, Ponti and Fiocchi who, together with Muzio, formed an architectural firm around 1920 in via S. Orsola.

Moretti was already the chair of Architecture in 1908 (previously held by Boito). With the collaboration of his assistant Piero Portaluppi, Moretti carried on the historical experience of his master, renewed in the light of new directions. In this formative context, we must refer to the drawings created by Castagnoli as a student prior to 1925, fully adhering to the consolidated direction of the Milanese school (figs. 2-5). In those years, as Guido Frette recalls in an interview (fellow student from 1919 to 1923) "we spent most of our time in the drawing room" and again "throughout the school there were twenty-five of us and we spent seven-eight hours in the drawing room" [Cartasegna, Santi 20 17, pp. 35 and 39].

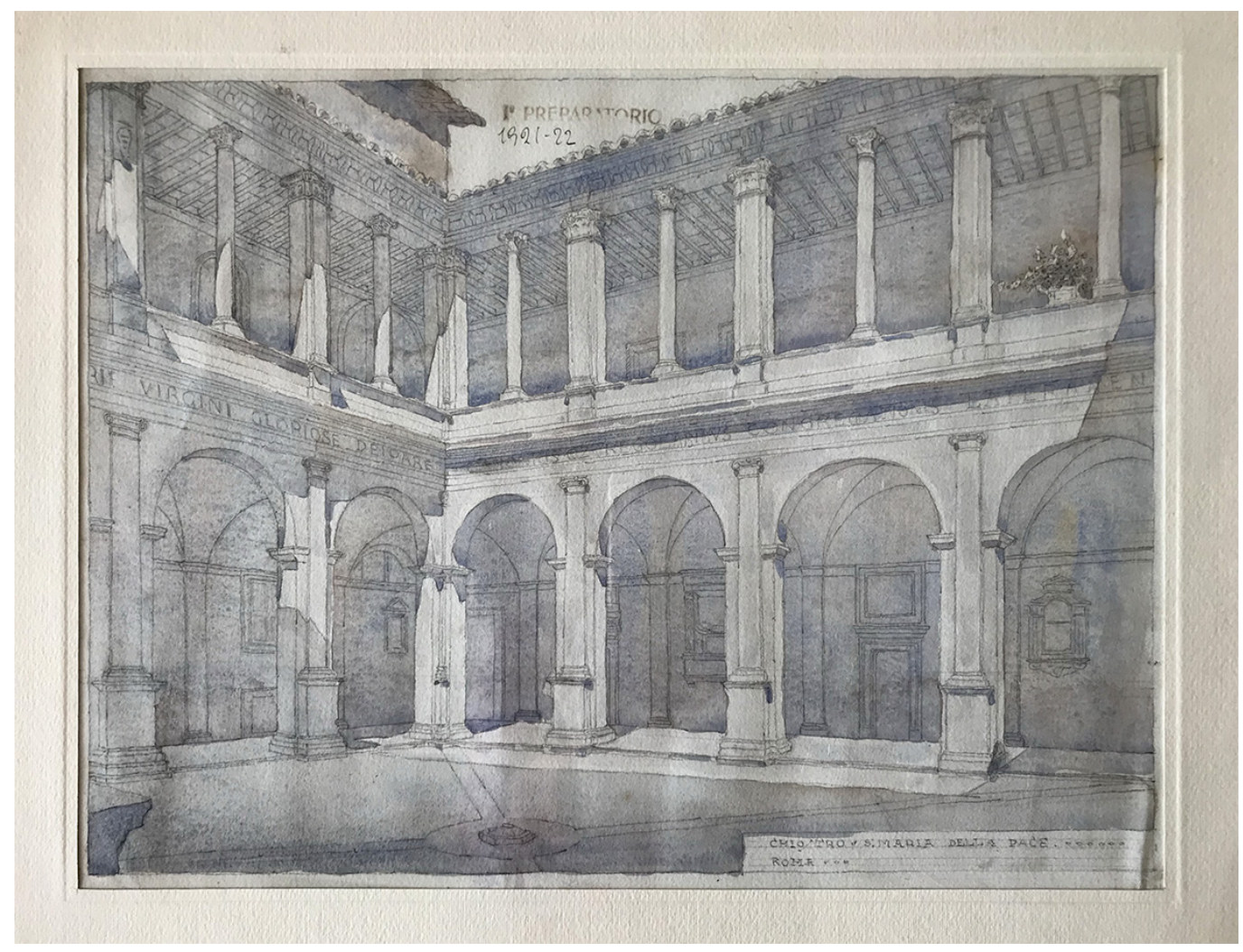


Only one year after graduating, the young architect participates in the establishment of Gruppo 7.The aim was to renew common architectural thought and the formal and functional research of Italian construction. Inspired by the demands of the Modern Movement, he also used new graphic language, which he resolutely adopted in the villa project for the fourth triennial of Monza [Caneva, Griffini 1930, pp. 55-59; Incerti 2016, p. 185]. As Frette narrates, however, Gruppo 7 never abandoned tradition, "Le Corbusier has completely abandoned it also in the designs, we have not. The difference between us and the other European rationalists is right there, they were scarse and more essential than us, we still had the recourse of things seen up to that moment" [Cartasegna, Santi 20 I7, p. 39].

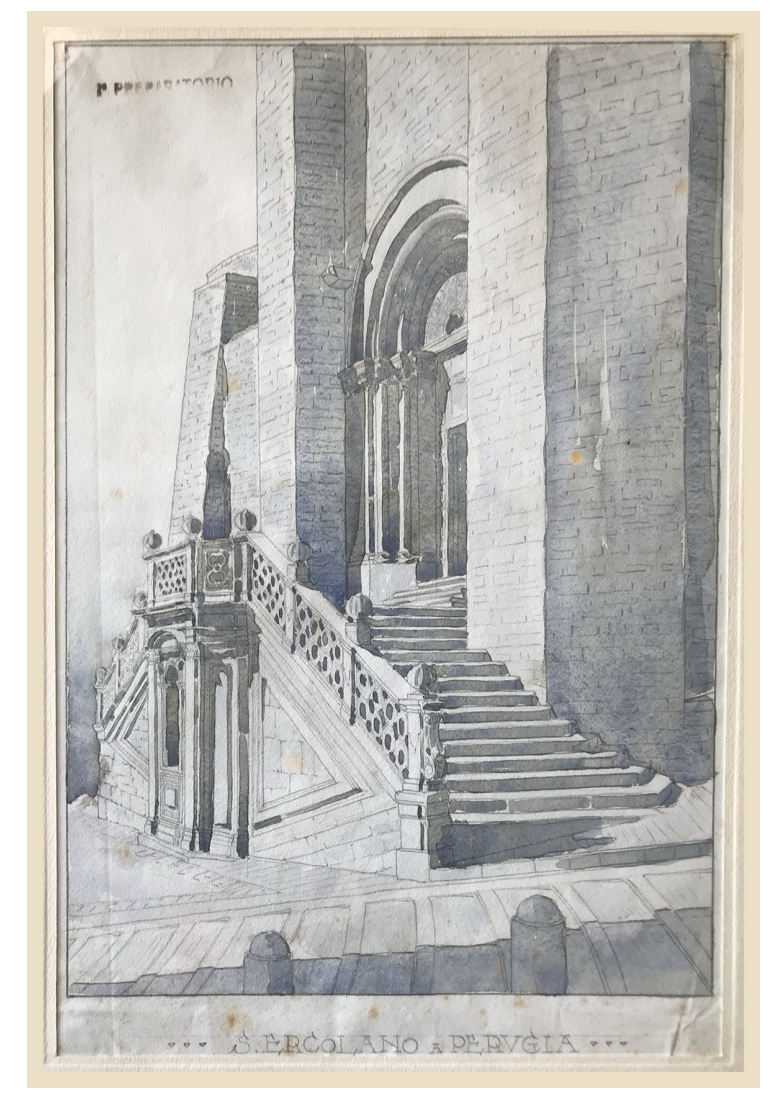

\section{Castagnoli's design for the applied arts}

Much has yet to be researched on the undoubted qualities of this little-known architect and designer. It is interesting to note that from the very beginning of his professional career he showed a flair for innovation, as can already be seen in the linear, geometrical design of the Gruppo 7 logo (fig. 6).

Ubaldo Castagnoli was a typical professional of his time. His education and training were substantial and wide-ranging, his skills as a designer being expressed in various areas - technical research, urban planning, the study of interesting architectural solutions and the design of objects.

In the mid-1920s decorative arts began to be transformed into industrial arts. It was at this time that, beside renowned designers and the artists and craftsmen they were flanked by, a new strategy was developed for the diffusion of products and their reproducibility.

Castagnoli found himself in the midst of this lively development, being involved, together with other colleagues, in the creation of forms for everyday objects.

The marriage was a particularly interesting one, since the innovation typical of his architecture found expression even here, albeit with certain limitations. The two facets -20th-century 
on the one hand, deriving from styles studied during his education, and rational (deriving from his own expressive research) on the other- is quite evident in the few known objects that carry his signature. We are referring here to two facets, the 20th-century one and the rationalist one, that coexist in the majority of architects of that time, as is now widely acknowledged.

The milieu of decorative arts exhibitions, initially the Monza Biennale (1923-1930) and later the Triennale in Milan (from 1933), revolved around key figures with whom Castagnoli had close relations. He himself participated in both, as an architect with the rationalist Villa al mare in 1930 (Velo 20 I6, pp. I 20-122) and as a designer with the embossed plate in 1933 (fig. 7), of 20th-century traditional taste (see, for example, the objects of Giovanni Guerrini in: Colombo Guerrini 2012), and two other objects in 1936.

The first of these is a bowl documented by the heliography of an autograph drawing [I] datable between 1933 and 1936, when Castagnoli designed objects for the Cooperativa Artieri Alabastro of Volterra for the 5th and 6th Triennale in Milan [Frattani, Badas 1976, p. 261; Turrini 2018, p. 92]. The drawing is precise and informative: its author has in fact meticulously represented the effect of the mineral to be used, highly conscious therefore of the object's aesthetic appearance. Moreover, on the left side of the elevation we can clearly distinguish indications of two versions of the inner curvature: one has a continuous line, as if delineating the section of the object, while another dotted line indicates a gentler, shallower curve. We have here a design that could be called executive, in which a consciousness of the line makes the idea absolutely clear.

Having traced the photograph of an unattributed bowl of 1936 in the archives of the Triennale identical to that of the design from the Volterra archive, we can suppose it is a realization of the one designed by Castagnoli. As far as the material is concerned, despite being a black and white photograph, we can intuit that the object is a lathe-turned agate bowl, as is suggested by indications on the drawing (the reference to red marble -rabescato rosso- is found in the heading, while the word agata is handwritten on the sheet in two places). It was, after all, fairly common to use prototypes that could be produced in a range of different

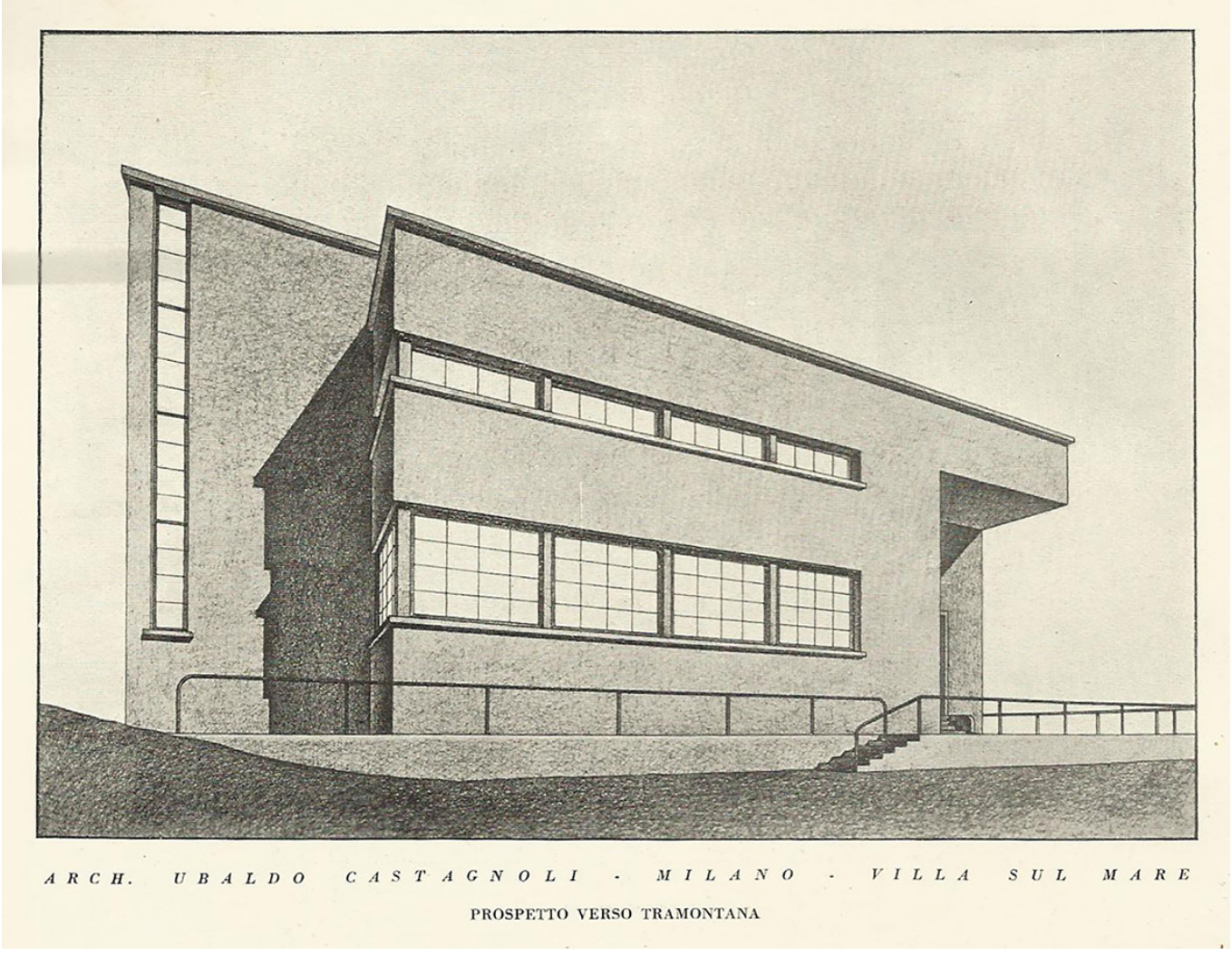


materials. Noteworthy are the lines carved into the stone at the base of the bowl and the much thinner lines on the upper rim, a motif that reappears in the wooden box dating from the same period (fig. 9). Here, the body of the extremely linear, modern object is crowned by a top decorated more in the Art Deco style.

Castagnoli worked with many other colleagues in various spheres, first of all as a member of Gruppo 7, as an architect who created long-lasting partnerships, and as a designer closely collaborating with artists and craftsmen through specific organizations. The most important of these was ENAPI, the Ente Nazionale per l'Artigianato e le Piccole Industrie, whose aim, among other things, was to promote and develop economic activity and the technical improvement of handcrafts and small industries through forms of technical and artistic assistance, and whose artistic director from 1927 to 1946 was G. Guerrini who specifically promoted the union of artists/designers and craftsmen. As regards Castagnoli's personal relations with prominent figures of the time, we should mention Antonio Cassi Ramelli with whom he participated in the competition for the Council Houses of Milan in the San Siro neighbourhood of 1932 [Rassegna di Architettura 1934] and with whom he continued to work as a STIPEL employee, involving Cassi Ramelli in various projects (e.g. the Cavour centre in Milan), as can be evinced from correspondence conserved in the TIM Historical Archive. Cassi himself was the architect of the STIPEL centre in Pavia (1954-56), a fact that reveals the interweaving of contacts and relations in which Castagnoli was involved (it suffices here to mention that his appointment with STIPEL was possible due to relations he had established through Gruppo 7).

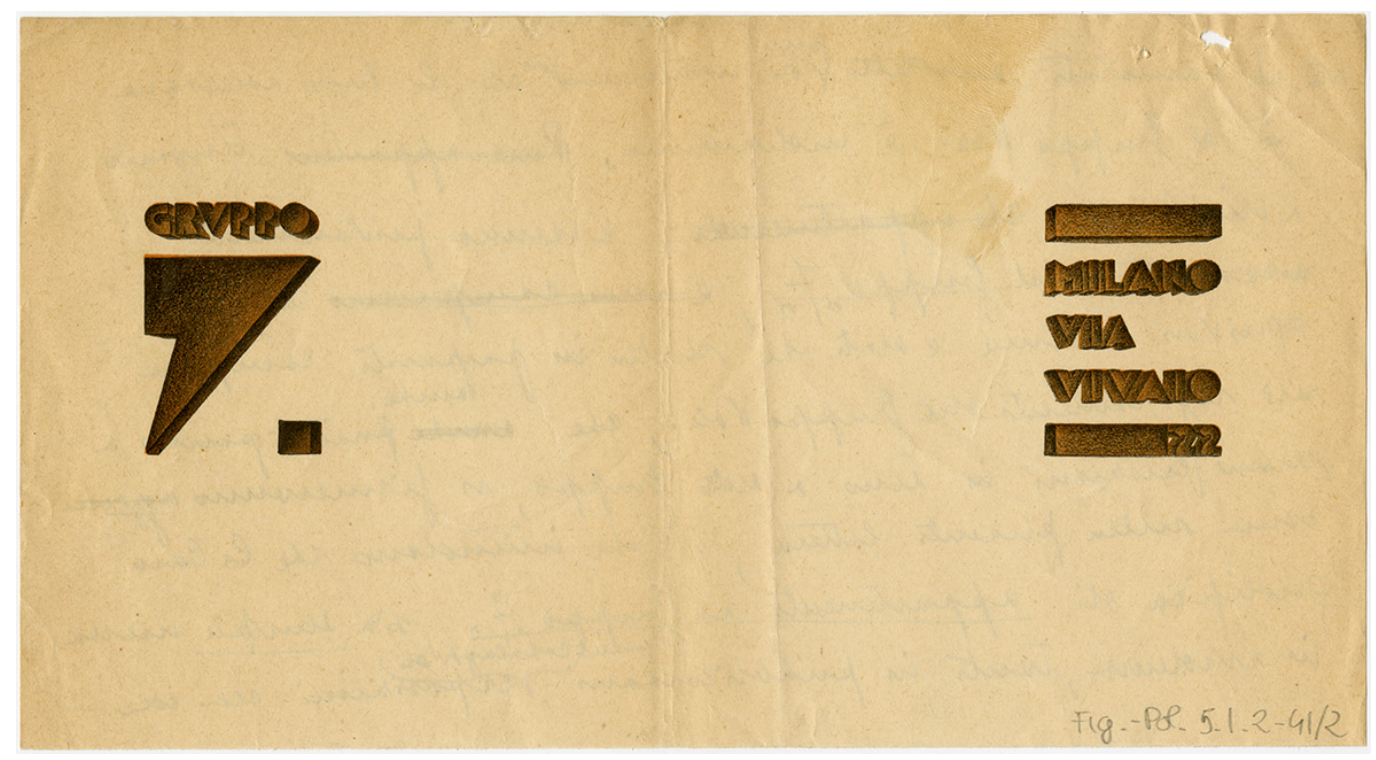

\section{One of the first projects for STIPEL: the building of Città Studi in Milan}

The growth of subscribers of STIPEL (Società telefonica interregionale piemontese e lombarda) in an area of strong expansion such as that of Città Studi and the impossibility of expanding the spaces occupied by the machinery already in use, led the telephone company to plan the abandonment of its premises located in the building principal of R. Politecnico di Milano in February 1938 and to design a new building.

The urbanization of this peripheral and rural area began in 1913 , with the general project of the entire university complex curated by the two teachers Augusto Brusconi and Gaetano Moretti [Ricci 2008]. The construction of this impressive work, consisting of nine connected buildings, was started in 1915 and, after the blockade of the war period, resumed in 1921 with the drafting of the final project until the inauguration of 1927. 
Fig. 7. Embossed plate made by the Nani firm of Bergamo, designed by the architect Ubaldo Castagnoli, exhibited in the E.N.A.P.I. room at the Mostrainternazionaledellearti decorative e Industriali, 1933 (photo by Crimella.

Fig. 8. Left: drawing of a lathe-turnedbowl in redmarble, signed Ubald Castagnoli, pencil on paper, Archivio Storico della Cooperativa Artieri Alabastro di Volterra, 1933- 1936. Right: bow exhibited in the Galleria delle arti decorative e industriali of the 6th

Triennale in Milan, 1936, (photo by Crimela
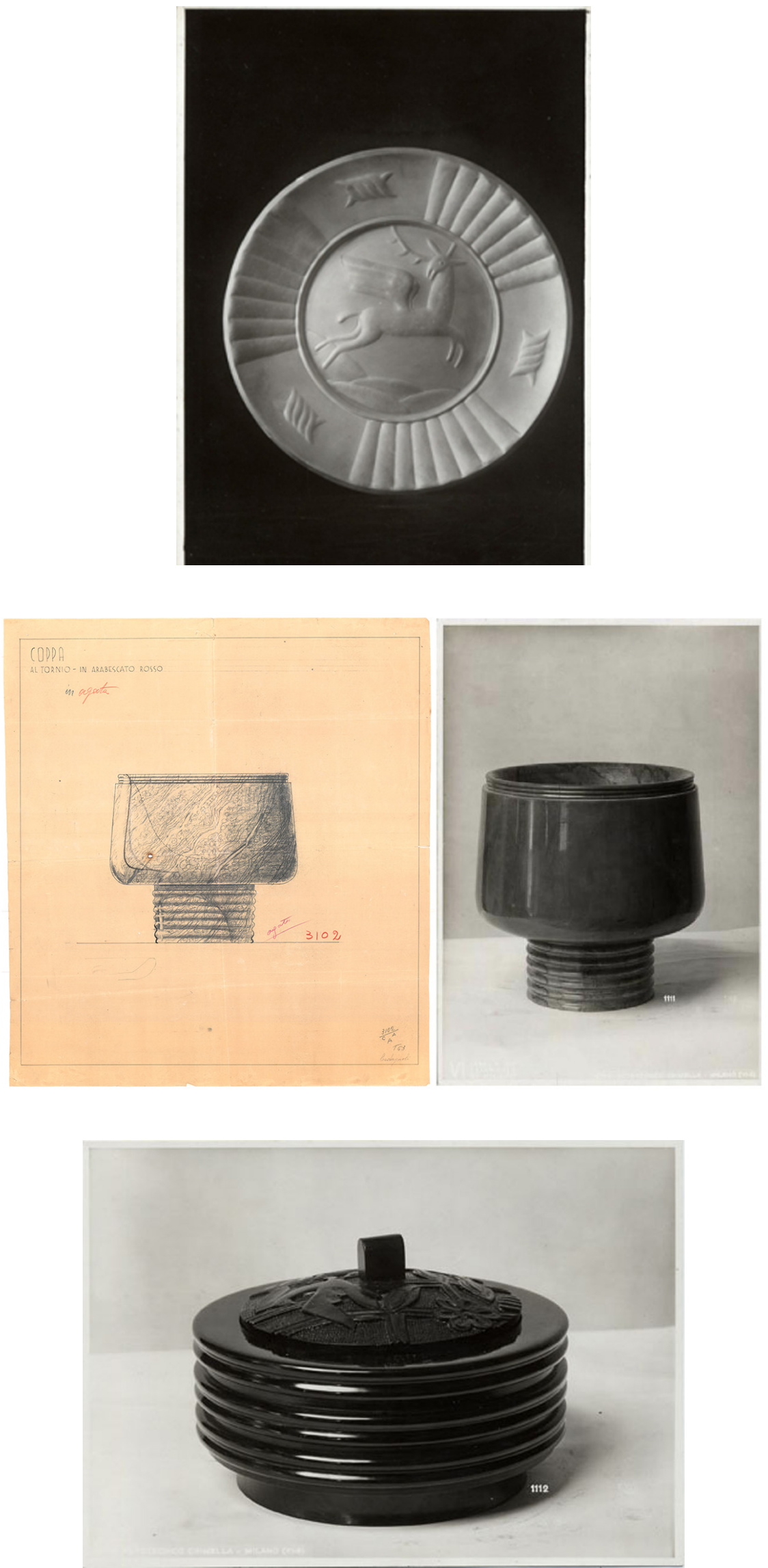
Fig. 10. New STIPEL

construction of Città

.

ot Castagnoli developed

building consisting of ard. In the base-

ment were the technical

rooms and warehouses,

while on the mezzanin

floor were the large

room called 'automatic', of about 300 square

meters, and the engine

room. The staff quarters

were located on the first

floor. A sketch testifies

that, instead of the

curved roof, a traditional

itched roof was ac

Ault (TMM Historical
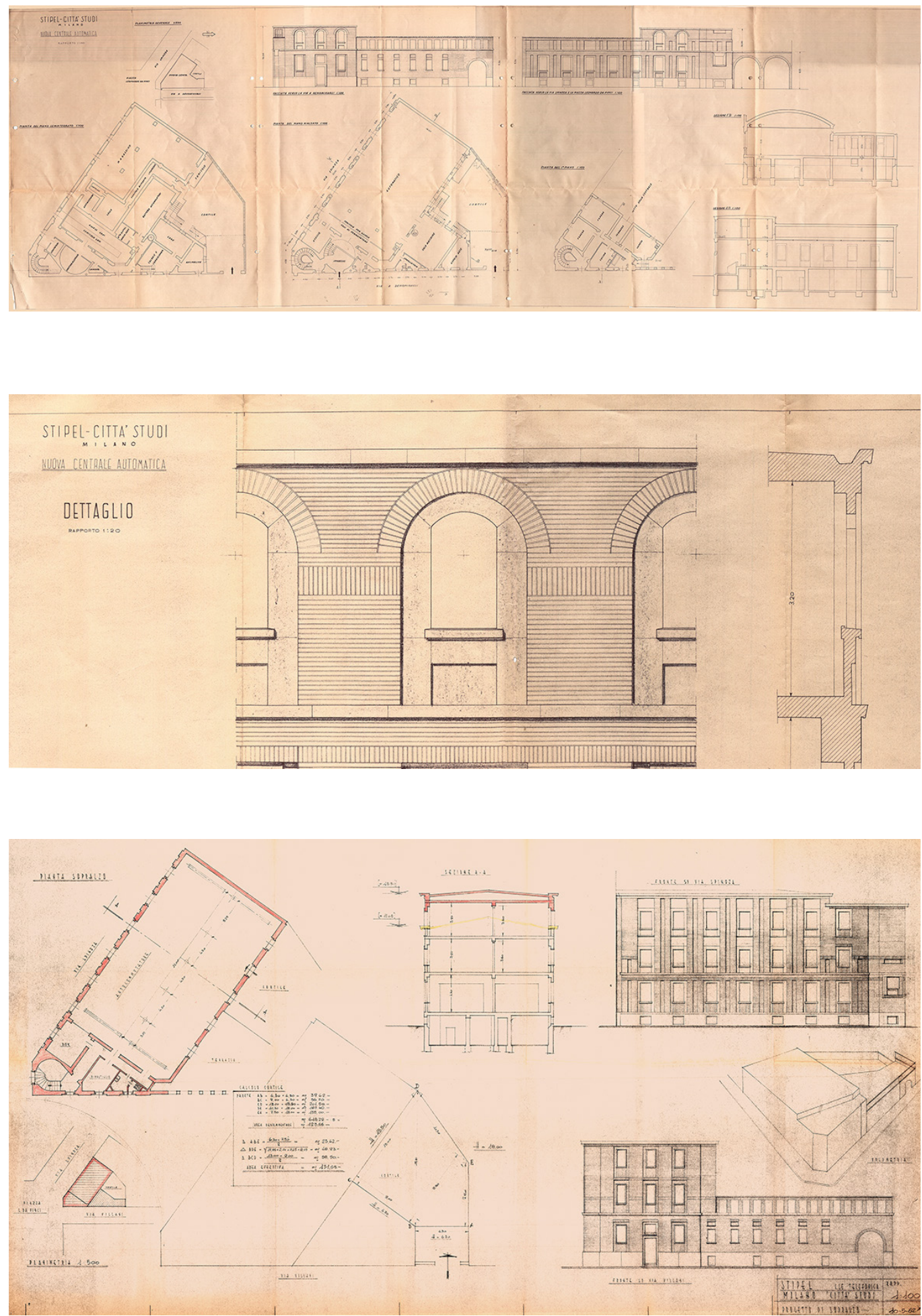

Fig. 12. Project for the elevation of the Città

Studi building dated 1962: a floor was added to the central body on Piazza Leonardo, while the roof of the 'automatic room' was demolished on $\mathrm{Via}$ Spinoza to add two more floors (Castagnoli Family Private Archive)

building in Città Studi.

The composition of the facade is characterized flat surfaces, necessary to mark the rhythm, to-

gether with the openings. large stone frames and high windowsills, together table. At the top, the theme of the loggla with rently on the south-west side (closed) compared to the east side (open)
(TIM Historical Archive folder $7 / 2$ ) 
The planimetric form of the new building is the result of a series of negotiations with the properties and the local administration, which authorized the use of a portion of the area located north-west of Piazza Leonardo where, in the immediate post-war period (1919), following the shortage of public housing, the Gran Sasso Garden Village was built. The expropriations and demolitions of residential buildings, which took place in 1939, mark the beginning of the executive phase of the project, which was carried out between 1940 and 1943 (therefore during the war) as well as attesting the contracts with the executing company (TIM Historical Archive - STIPEL Fund - DCT Series, Technical Central Management - SE Subseries, Construction Service - Folder 7/2).

The design of the elevations shows the use of a contemporary language: the roofs are visually perceived as flat, even though the roof of the large engine room has a lowered arch section (with a span of $14 \mathrm{~m}$ ) hidden by a small sail (figs. 10-12). This is a technologically and geometrically innovative solution for the time, since the arch structure with reinforced brick beams called Volta SAP for large roofs (up to I5 meters) was exposed in the building sector of the 1938 Milan trade fair for the first time. The system had been patented in 1936 and was produced by the Fornaci brothers Rizzi Donelli Breviglieri \& C. of Piacenza. The same technology was used by Giuseppe Pagano in the expansion project of the Nuova Pettinature Riunite building in Biella in 1939, in collaboration with Eng. Predaval [Paolini, Pugnaletto 2017].

Circular and semicircular shapes characterize the plan of the entrance, that of the stairwell, the openings of the second level, the two arches of access to the current Via Villani (never completed even if it was set, as you can see from the fragment still existing today) and the entrance to the courtyard. If the variation of these geometries is undeniably close to the Milanese twentieth century language, the use of the Volta SAP technology highlights Castagnoli's attention to innovative construction solutions.

With these first reflections, a new research begins on the figure of the architect Castagnoli, member of Gruppo 7. It will be conducted on the basis of the unpublished and conspicuous graphic documentation kept in the numerous consulted archives [2].

\section{Notes}

[I] One of the unpublished drawings, belonging to the Historical Archive of the Cooperativa Artieri Alabastro of Volterra, available thanks to a project of reorganization and cataloguing under the scientific direction of Prof. D. Turrini, University of Ferrara - Department of Architecture, financed by MIBACT - Direzione Generale per gli Archivi (Servizio III - Studi e Ricerche), 2014-2017, under the supervision of the Soprintendenza Archivistica per la Toscana.

[2] Uliva Velo wrote the paragraph Castagnoli's design for the applied arts; Anna Castagnoli wrote the paragraph Biographical notes; Manuela Incerti wrote the paragraphs Castagnoli and the Milanese school and One of the first projects for STIPEL: the building of Città Studi in Milan.

\section{References}

Bernardi llaria, Aguirre Álvaro Soto (20।8). L'apprendimento della rappresentazione dell'architettura: Figini e Pollini nell'età del Gruppo 7. In Disegnare. Idee Immagini, 56, 2018, pp. 80-91.

Buratti Mazzotta Adele (20 I3). La didattica del disegno edile e la cultura delle scuole tecniche nell'Ottocento a Milano. In: C. G. Lacaita, M. Fugazza (a cura di). L'istruzione secondaria nell'Italia unita: I 86 I - 1901. Milano: FrancoAngeli, pp. 258-273.

Caneva Luigi Maria, Griffini Enrico Agostino (1930). 36 progetti di ville di architetti italiani. Milano-Roma: Bestetti e Tumminelli.

Cartasegna Roberto, Santi Brunetta (a cura di). (2017). Franca Petocchi intervista Guido Frette. In Brunetta Santi, Cartasegna Roberto (acura di). Guido Frette un razionalista a Tortona. Catalogo della Mostra, Biblioteca Civica di Tortona 26.XI.20 I6 25.II.20 17. Tortona: Città di Tortona, pp. 33-45.

Ciucci Giorgio, Muratore Giorgio (20 I0). Storia dell'architettura italiana. Il primo Novecento. Milano: Electa.

Colombo Guerrini Elisabetta (20 I2). Giovanni Guerrini. Metalli, Imola: La mandragora.

Frattani Paola, Badas Roberto (1976). 50 anni di arte decorativa e artigianato in Italia. L'Enapi dal 1925 al 1975. Roma: Enapi.

Incerti Manuela (2016). Le ville del concorso della IV Triennale di Monza (1930). Disegno e modello nella comunicazione del progetto. Bologna: Bononia University Press. 
Istituto per le case popolari Milano (1933). Il concorso pel nuovo quartiere Francesco Baracca a San Siro : progetti di massima pel nuovo quartiere Maurilio Bossi in viale Molise. Milano: Bertieri.

Moretti Gaetano (a cura di), (sd). Studi di architettura della scuola superiore nella R. accademia di Belle Arti e nel R. Politecnico di Milano. Milano: Bestetti e Tuminelli.

Paolini Cesira, Pugnaletto Marina (2017). Reinforced brick light-weight vaults. In Tema: Technology, Engineering, Materials and Architecture, 3, I, 6 luglio 2017, pp. 124-136.

Rassegna di Architettura (193I). La II Esposizione di Architettura Razionale Italiana alla Permanente di Milano. In Rassegna di Architettura, IX, 7, I931, pp. 249-257.

Rassegna di Architettura (1934). P. Buffa, A. Cassi architetti. In Rassegna di Architettura, num. spec., 1934.

Ricci Giuliana (2008). Una sede sofferta: dalla preesistenza a un nuovo insediamento urbano. In Annali di storia delle universita italiane, 12. Bologna: Clueb, pp. 27-44.

Selvafolta Ornella (2008). Una scuola per il progetto. La formazione tecnico scientifica al Politecnico di Milano. In Milano scientifica, 1875-1924. Milano: Sironi.

Selvafolta Ornella (20/2). Gli studi di ingegneria civile e di architettura al Politecnico di Milano. Territorio, costruzioni, architetture. In Le università e l'unità d'Italia, 1848-1870. Bologna: Clueb.

Turrini Davide (20 I8). Alabastro e design. Gli Artieri di Volterra dal 1933 al 1953. In LUK, 24, 20 I8, pp. 85-96.

Velo Uliva (2016). La «villa moderna». Riletture dei progetti di concorso. In: Incerti Manuela. Le ville del concorso della IV Triennale di Monza (1930). Disegno e modello nella comunicazione del progetto. Bologna: Bononia University Press, pp. I03-I49.

\author{
Authors \\ Uliva Velo, Università di Ferrara, uliva.velo@unife.it \\ Anna Castagnoli, Università di Ferrara, anna.castagnoli@gmail.com \\ Manuela Incerti, Università di Ferrara, manuela.incerti@unife.it
}

To cite this chapter. Velo Uliva, Anna Castagnoli, Incerti Manuela (2020). Ubaldo Castagnoli. Dal Gruppo7 alle architetture per le telecomunicazioni/Ubaldo Castagnoli. From Gruppo 7 to architectures for telecommunications. In Arena A., Arena M., Brandolino R. G., Colistra D., Ginex G. Mediati D., Nucifora S., Raffa P. (a cura di). Connettere. Un disegno per annodare e tessere. Atti del $42^{\circ}$ Convegno Internazionale dei Docenti delle Discipline della Rappresentazione/Connecting. Drawing for weaving relationships. Proceedings of the 42th International Conference of Representation Disciplines Teachers. Milano: FrancoAngeli, pp. 2869-2890 